\title{
Neo-Modernity: \\ A New Framework \\ for Political Reality
}

\section{The Middle Eastern Case}

\author{
Vassily A. Kuznetsov
}

\author{
Vassily A. Kuznetsov, PhD in History \\ Institute of Oriental Studies of the Russian Academy of Sciences, Moscow, Russia \\ Head of the Center for Arab and Islamic Studies \\ SPIN-RSCI: $8052-7393$ \\ IstinaResearcherID (IRID): 3553785 \\ Scopus AuthorID: 57196044428 \\ E-mail: vasiakuznets@yandex.ru \\ Address: 12 Rozhdestvenka Str., Moscow 107031, Russia \\ DOI: $10.31278 / 1810-6374-2020-18-2-132-154$
}

\begin{abstract}
This paper explores the possibility of considering neo-modernism as a framework concept for studying political processes in the Middle East. The study starts with an analysis of the notion of neo-modernity as a new way of treating reality that emerged out of postmodernism as a reaction to its totalizing criticism. A comparative analysis of the main publications on the matter has revealed key features of neo-modernism: the ability to avoid postmodern fragmentariness, problematization of values and meanings, and return to metanarratives. In the political realm, these features manifest themselves in five ways: the search for new political unities; the growing demand for projects of the future and for ideology; the creation of a new political mythology; the use of postmodern tools in political practice; and awareness of the fundamental instability of the current state of affairs. The main features of neo-modernism have been scrutinized with reference to the specific Middle Eastern political reality at the regional, national, and
\end{abstract}


social levels. This approach has revealed the search for new regional, subregional, and national unities in the Middle East, as well as the creation of new ideologies, often directly related to attempts to devise new national development strategies, and the emergence (and sometimes deliberate engineering) of new elements of political mythologies.

Keywords: neo-modernity, postmodernity, the Middle East, the Arab world, Islam

Thematically and methodologically, this paper is a continuation of my essay published in Russia in Global Affairs a year ago

(Kuznetsov, 2019), as well as several earlier works. This article pursues two goals: first, it seeks to add new touches to the concept of neo-modernity and, second, it attempts to use it for analyzing current political processes in the Middle East.

\section{NEOMODERNITY AS A FRAMEWORK CONCEPT FOR TODAY'S REALITY: HISTORIOGRAPHIC SETTING}

Although at first glance the word 'neo-modernity' does not look particularly original and seems to be almost clear in meaning, the set of ideas it is meant to convey is very difficult to describe. Russian researcher A. Pavlov was probably right when he said that "what could be called the concept of 'neomodernism' hardly exists as something well-defined or at least understandable" (Pavlov, 2019, p.195). This is what makes neo-modernity basically different from meta-modernity conceptualized by R. van den Akker and T. Vermeulen (2019, pp.3982) and from other variants of postpostmodernism (performatism, altermodernism, digimodernism, automodernism, etc.).

For all its drawbacks, this situation certainly gives us obvious advantages: conceptual incompleteness offers ample opportunities for further theoretical pursuits.

And yet, it would be appropriate to revisit the writings (there are not so many of them) that draw on the concept of 'neo-modernity. Leaving aside very specific works on architecture, where 'neo-modernity' means a certain style characterized by simplicity and functionality 
(Ciarkowski, 2016), I will focus on those publications whose authors, even while talking about individual cultural phenomena, view neomodernity as a broader notion.

In total, there are about a dozen such texts. The first publication I know of, which used the term 'neomodernism,' was an article by art critic Victor Grauer, Modernism/Postmodernism/Neomodernism (Grauer, 1981-82). A decade later, it was followed by American sociologist Edward Tiryakian's article, Modernization: Exhumetur in Pace in 1991 and his other article, Retinking Modernization: Legacies of Parsons and Hilbert in 1996; L. Vyazmitinova's review of D. Vodennikov's 1999 book of poems Holiday; two neo-modernism manifestos published in 2000 by Western painters-one by Guy Denning and the other one, by Arman Bayraktar, André Durand, and Scott Norwood Witts; a 2003 monograph by American sociologist Jeffrey Alexander, The Meanings of Social Life: A Cultural Sociology, (Russian-language edition 2013); a monograph of literary scholar A. Zhitenev, The Poetry of Neo-Modernism (2012); works by Polish film critics Rafał Syska (2014) and Miłosz Stelmach (2016) dedicated to neo-modern cinema (2012-2016); a manifesto by Russian philosopher and cultural scientist A. Pelipenko (2016) and its review by O. Glukhova (2016); analytical articles posted on the RIAC website by E. Alekseenkova in 2016 (while avoiding this term, she nevertheless refers to articles on neo-modernity and argues with their authors) and by A. Kortunov and I. Gibelev in 2017; a philosophical article by I. Gibelev, Neomodernity as an Opportunity (2018); and finally an article by art historian Michael Eden, Neo-Modernism: Soul Nourishing Renaissance (2018). I deliberately did not include my own texts in this list of publications.

Even a cursory look at this list reveals some peculiarities.

Firstly, the works mentioned above belong to completely different fields of humanitarian knowledge: philosophy, theoretical sociology, applied political research, literary and art studies. The first works to be published were written by literary scholars and artists. Then followed publications written by sociologists and political researchers, and only later, by philosophers (standing out among them are articles by V. Grauer and 
E. Tiryakian, which were written much earlier than the others and were almost unrelated to them). Such an order is obviously due not only to basically different genres of the publications (from artistic manifestos to monographs), but also to the specificity of different spheres of knowledge, which require different time to comprehend reality and produce texts.

Secondly, putting aside Grauer's article, which stands quite by itself, one can see that most of the texts were published in two waves-in 1991-2003 and 2012-2018, and it seems that the authors of the second wave hardly paid much attention to their predecessors, although some of them knew about their works. Several lines of knowledge continuity can be traced here. For example, J. Alexander mentions E. Tiryakian's article, and I. Gibelev refers to publications by E. Alekseenkova (2016), A. Kortunov (2017), and V. Kuznetsov (2019), although in his latest article he does not mention them. G. Denning and a group of painters led by A. Bayraktar seem to have known about each other's manifestos, and M. Eden read both. Finally, A. Zhitenev mentions a review by L. Vyazmitinova. So, here is a typical situation of fragmented knowledge where artists read artists, sociologists read sociologists, etc., but none of them has the whole picture.

Presumably, both groups of texts were prompted by a sense of a fundamental change in the surrounding reality and the need to find new mechanisms to explain it.

The authors of the first wave were fully aware of this situation. And although they attributed it to different circumstances, explicitly or implicitly it correlated with the events of the late 1980s and early 1990s, which not only put an end to the bipolar system of international relations, but also forced painters and writers to rethink both the surrounding reality and their relations with it. E. Tiryakian understood "neo-modernization" as an urgent need to revive the theory of modernization in the new global political and economic conditions. Jeffrey Alexander notes that in politics neomodernism has gained power because political revolutions of the last decade have revived a truly heroic narrative, thus expressly defying the postmodern decline (2013, p.572). While exploring the origins of neo-modernity, L. Vyazmitinova speaks about attempts to overcome 
the "unsupportedness" of postmodernism and the fragmentariness of the author's "self" caused by it; G. Denning talks about the oblivion of "aesthetic sensitivity" and the diktat of artistic policy and political correctness (this resonates with V. Grauer's thoughts); and A. Durand states the death of art as such. In general, all these texts have one thing in common: fatigue from postmodern play and the striving for a new sincerity, which was predicted by V. Grauer and which was then extolled by some metamodernists (Eden, 2018), while others preferred to talk about "post-irony" (Constantinou, 2019), contrasting it with the previously discovered "new sincerity" (Kelly, 2010).

The authors of the second wave reason differently.

A. Pelipenko, in a rather hysterical manner reminiscent partly of the Soviet agitprop of the 1920s and partly of post-Soviet non-mainstream radical publications, predicts an anthropological catastrophe if mankind does not abandon decadent postmodernism ("Down with postmodernism in public life, policy and morals! Down with all its discourses and creations: political correctness, multiculturalism, pacifism, and left-wing liberal ideology!" (2016, p.49)) to turn to the principles formulated by the authors of neo-modernity (whether provocative or insane): human rights are determined by the cultural and civilizational system to which a person belongs, violence is the normal language of culture, war is natural, and political correctness is evil (2016).

Film critics, when talking about neo-modernism in a specific professional way, compare it with the so-called "slow cinema" (A. Sokurov, et al.) of the 1990s-2000s which reawakens modern conceptuality and self-reflection (Stelmach, 2016, pp.104-106). Neomodern cinema, blooming in countries long thought to be on the fringes of film-making (Thailand, Taiwan, Hungary, etc.), is rooted in local artistic traditions but at the same time fully integrated into the global network of artistic and economic ties, and its artistic language is quite universal (Stelmach, 2016, p.112).

For I. Gibelev, neo-modernity means "self-temporalization of man, conditioned on the responsibility of mind for determining the horizon of a different reality, and occurring amid radical historicity of all finite things in existence" (2017, p.32). It means the renewal of history after 
its declared end, the ability of man to once again become a subject of a historical process.

The cinematic and philosophical understanding of neo-modernity is quite consistent with its interpretation by M. Eden. Having called his article Neo-Modernism: Soul Nourishing Renaissance, the artist focused on the need to revive universal values, while taking into account the criticism that postmodernism leveled at its predecessor (2018).

Finally, A. Kortunov, looking at neo-modernity exclusively from the international political angle, points to its four basic characteristics of neo-modernism: nationalism, transactionalism, holism, and historicism (2017). It should be noted that thirteen years earlier, J. Alexander viewed nationalism as the main evil in the universalistic world of neomodernity (2013, p.584). In his opinion, it is "nationalism rather than traditionalism, Communism or the 'East' that is becoming the main adversary of the universalized discourse of the good. Nationalism is the name that intellectuals and the public ever so frequently give to the negative opposites of civil society" (Alexander, 2013, p.584).

The multiplicity and incoherence of these interpretations make one wonder whether there is some meaningful core to the idea of neo-modernity understood differently by different authors, or whether "neo-modernity" is only a more or less randomly chosen word used to describe a completely new, or perhaps even nonexistent, phenomenon.

At first glance, the second answer is closer to the truth. Almost all authors contrast the state of neo-modernity with the state of postmodernism, but they understand the very essence of the latter and the method of contrasting differently. While some simply deny postmodernism (A. Pelipenko), (most) others talk about overcoming it, taking into account postmodern criticism, and still others insist that there has always been an alternative to postmodernism (A. Zhitenev).

It is also remarkable that, despite the seemingly obvious need to turn to the concept of modernity, not all do so when they talk about neo-modernity. Neo-modernity acquires its positive qualities not in the modernist tradition, but precisely in the denial of properties attributed to postmodernism. 
There are several exceptions, the most vivid of which is A. Zhitenev who wrote: "Contrary to the established research tradition, the Russian poetry of the 1960s-2000s can hardly be considered in the context of postmodernism as an aesthetic system since both the categories and aesthetic problems just indicate a revision of initial principles of modernism and avant-garde, but not a transition to a different type of artistic consciousness. The term 'neomodernism' emphasizing the renovation of poetic paradigms seems to be more appropriate" (2012, p.467).

A. Zhitenev makes yet another important point: neo-modernity can also be interpreted as both a new way to write about reality and a new way to read what has already been written, or a new perspective of analysis.

Since the texts being reviewed include both analytical works and manifestos, we can distinguish three main approaches stated in them: neo-modernity as existing reality, neo-modernity as an impending reality, and neo-modernity as a desirable reality. All contradictions between these approaches evaporate if we understand neo-modernity not as reality per se, but as a way to treat it. In other words, the way we read a text, not the way we write it.

Despite all the flaws noted above, it still seems possible to find some meaningful core in the concept of neo-modernity: all the publications under consideration mention three sets of ideas.

The first one suggests overcoming postmodern fragmentariness of the text, the author's ego or reality. Depending on how the authors understand postmodernism, they can find this overcoming either in the new universalism (J. Alexander) or, on the contrary, in particularism (A. Kortunov), which, however, are not necessarily antagonistic to each other. For example, A. Zhitenev notes: "For postmodernism the world appears as chaos in which both the subject and the text created by it are in a state of disintegration. Fragmentariness comprehended as a universal property of life motivates the rejection of all sorts of 'essentialism,' rhizomatic structuring of the text, and elimination of valuable and semantic oppositions.

"In neomodernism the nonlinearity of a statement is connected not with the fragmentariness of the world, but with the idea of its 
multidimensionality. Stratification of the text represents not the disintegration of consciousness, but a plurality of untraceable connections which exclude sequential deployment in integrated space. The structure of a statement is thus preserved, but it does not cover the text as a whole" (2012, p.468).

The second set of ideas concerns the problematization of values and meanings. The world of neo-modernity is a world of revived values, a world that is searching for great purposes of existence. Remarkably, it is not important which particular purpose to seek. What is important is the desire to find support in them. The problem is not that some authors understand neo-modernity as a return to the universal values of modernity and the idea of progress, while others, on the contrary, see it as rootedness, nativism, and tradition. One way or another, all these are different sides of the same coin.

The problem is that postmodern relativism was philosophically justified by a number of authors, particularly J. Lyotard, who wrote that "simplifying to the extreme, I define postmodern as incredulity towards metanarratives" (1998, p.10). And since it was justified, it is impossible to simply dismiss it.

This takes us to the third set of ideas, those related to the notion of narrative. Even when authors contemplating about neo-modernity do not speak openly about the revival of metanarratives, the matter in question is invariably this aspect anyway. Suffice it to read the texts written in the logic of French post-structuralism which is traditionally perceived in Russia as one of the variants of post-modernism. J. Alexander's reflections on revolution and heroism, the return of aesthetics in G. Denning's manifesto, the Hegelianism of Bayraktari and his adherents, Eden's "soul revival," etc.-all this requires reanimation of the discourse on narratives.

However, none of these authors answers the question of how it is possible to return to metanarratives without wiping from memory Europe's intellectual experience of the last fifty years. The only possible solution probably is to use postmodern instruments, rather than abandon postmodernism - not for restoring the bygone trust in the ideas of revolution, progress or unconditional beauty, but for redesigning the myths about them. 
To sum up the ideas stated above: When we speak about neomodernity, we actually speak about a global phenomenon, which is not yet completely clear and which various authors have been trying to grasp for several decades. In the most general sense, this phenomenon can be described as a new way of treating reality, which has emerged in the wake of postmodernism as a reaction to its totalizing criticism. From the sociopolitical point of view, the emergence of neo-modernity was a reaction to the securitization of the world after F. Fukuyama's "end of history" - postmodern lack of anchorage did not bring the common good, but a common sense of insecurity.

As a global phenomenon, neo-modernity manifests itself, among other things, in the realm of politics at least in five basic ways.

First, attempts to overcome fragmentariness in politics suggest a search for new unities at different levels: social, national, subregional, regional, trans-regional, and global. This, in turn, naturally encourages competition between various projects, both integrational and secessional ones. Examples include not only the Brexit or regional separatism in various European countries, but also integration processes in the post-Soviet space, competition between the APR and IPR concepts in Asia, and the renewed discourse on national sovereignty which has once again become quite popular in world politics (Ilyin, 2011; Akopov and Krivokizh, 2019).

Second, the problematization of the values and meanings of sociopolitical existence spurs demand for new future-oriented projects. Together with the reemergence of metanarratives, this leads to the return of ideology (Rudenkin and Loginov, 2018). Hence the rebirth of both right-wing and left-wing populism in Europe and beyond (Huber and Schumpf, 2017).

Third, the return of metanarratives also suggests public demand for new political mythology, as pointed out by J. Alexander (2013, p. 512) and borne out by mass protest movements around the world in the last ten years.

In epistemological terms, the return of metanarratives leads to the emergence of a new political language when the political process begins 
to be understood as coexistence and competition of various narratives (Kuznetsov, 2018).

Fourth, the contradictory relationship between neo-modernity and postmodernism, the impossibility of discarding the latter, the destruction of modernist hierarchies, and the coexistence of various narratives about reality in a single sociopolitical space make it necessary to use postmodern instruments (irony, play) for organizing this space; hence the concepts of a world of post-irony and post-truth (Constantinou, 2019).

Finally, the fifth manifestation is that such a situation raises awareness of the unstable, intermediate, and transient state of the modern world. The discourse on the transformation of the world order becomes both habitual and perpetual. In this regard, the concept of neo-modernity is close to the idea of meta-modernity based on the postulate of "inbetween" state (van den Akker and Vermeulen, 2019, pp. 60-63).

\section{NEO-MODERNITY AND THE STATE IN THE MIDDLE EAST}

Oddly enough, the transition to the state of neo-modernity in politics has become manifest most distinctly not in developed Western countries zeroed in on by van den Akker and Vermeulen (2019, pp. 60-63) when they refer to meta-modernity, or by Fredric Jameson when he analyzes postmodernism as the "logic of late capitalism" (2019), but in the Middle East. However, this will be less surprising if we remember that the concepts of modernity and postmodernism, according to Perry Anderson's shrewd observation, "were born in a distant periphery rather than at the center of the cultural system of the time: they come not from Europe or the United States, but from Hispanic America," and one of the founders of postmodernism was literary critic Ihab Hassan of Egypt, the son of the Mansoura governor under the monarchy (1998).

It is the Middle East that has experienced (and is still experiencing) the most radical, multidimensional and multifaceted transformation in the last decade, comparable, in terms of depth and impact on world politics, with the events of the late 1980s and early 1990s in Central and Eastern Europe and the post-Soviet space. This region has become a source of new threats, challenges and opportunities for 
global players. Well-known Arab exceptionalism (El Hamalawy, n.d., p.3), ${ }^{1}$ the sort of political formalin of the Middle East, has provided for the coexistence of premodern elements in political cultures and systems, modern aspirations in social life, and postmodern governance practices. At the same time, the specific demographic situation and a large share of young people integrated into global humanity and rooted in local traditions, gave societies in the region the necessary impetus for transformation, which has led to progress in some places, caused tragedy in others, or turned into a farce.

Contrary to the popular view, the fragmentariness of the Middle East is not a consequence of the Arab Spring, but one of its causes (Soler i Lecha et al., 2016, p.43). ${ }^{2}$ And it is this fragmentariness that the region has been trying to overcome all these years. At the regional level, this manifests itself in the search for new unities that compete fiercely with each other. In addition to the actual Middle Eastern and Islamist projects described in my previous article (Kuznetsov, 2019), I can mention four more here.

First, the Arab one, existing as a specific geopolitical project of the so-called Arab NATO and as an ideological construct created by some analysts (those in the Emirates, but not only them) (Alrawi, 2019) dreaming of a new edition of Arab nationalism, and finally as a palpable public reality that manifests itself through consolidated collective action in different countries of the region, be it the Arab Spring, the 2019 protests in Iraq, Lebanon, Egypt, Sudan, and Algeria, or the participation of Arab volunteers in different paramilitary antisystem movements.

\footnotetext{
"The MENA region has long been regarded as 'the Arab exception,' often characterized by scholars as the foremost example of an exception to the globalization of democracy by emphasizing the uniqueness of lack of democratic progress and remarkable resilience of the regimes, consequently leading to conclusions of a durable authoritarianism" (El Hamalawy N., n.d.)

$2 \quad$ "In 2011 and early 2012 there was still a widespread belief in the potential for more regional integration and cooperative security mechanisms (Malmvig, 2013). In fact, the active role of the League of Arab States and the Gulf Cooperation Council (GCC) when the crises erupted in Libya, Syria and Yemen, as well as the calls to revitalize the Arab Maghreb Union, seemed to indicate that this was happening. However, those expectations were soon dashed, as all those organizations remain hostage to rivalries among different regional and subregional powers as well as to dysfunctional institutional settings" (Soler I Lecha E. et al., eds., 2016)
} 
Second, these are bloc projects such as Egypt-Saudi-Arabia-UAE, Turkey-Qatar, Iran-Damascus-Hizballah, and others. None of them is institutionalized, each is plagued with serious contradictions and there is even direct competition between their participants, with cooperation being restricted and never extending to certain areas even in regional policy. For example, Riyadh has only limited support for its foreign policy initiatives from Cairo, but the UAE and Iran remain its key economic partners, despite their political confrontation. All this raises doubts about the sustainability of blocs. Indeed, authors often prefer to speak not so much about blocs as about ad hoc alliances. And yet, at the core of each of these regional axes lie not only geopolitical interests, but also ideology, commonality of narratives and certain similarities in how they see the desirable future.

Third, these are subregional projects of the Gulf, Maghreb, the Fertile Crescent, and the Nile Valley, which were glued together in the 20th century to form the modern Middle East (Baranovsky and Naumkin, 2018, pp.34-35). Clearly, neither the Nile Valley nor the Fertile Crescent (a name that evokes bitter irony today) has been institutionalized in any way; the Arab Maghreb Union has actually been inactive since 1994, and the GCC has not only always been in opposition to the two largest Gulf states, Iraq and Iran, but has also been heading towards a split (Kinninmont, 2019, pp.19-28). However, one cannot but notice cultural, political, and economic commonality in each of these subregions and the existence of developed subregional identities (Karolak, 2019).

Finally, fourth, we can talk about unity at the country level and commitment to strengthening national identities in different states of West Asia and North Africa. It would be opportune to recall mass movements in Iraq (Shakir Karim, 2020) and Lebanon (Wimbledon, 2019), as well as the non-intervention drive of the Algerian protests (their participants referred to themselves as "grandchildren of 1954" and called their protest "family business," in which foreigners should not interfere), or the policy of national consolidation declared by the leaders of Saudi Arabia (Alhussein, 2019), Qatar (Griffin, 2018), the UAE, Tunisia, and other countries. 
There is nothing new about these four forms of self-identity of West Asia and North Africa (WANA). For the most part, they have existed there if not always then at least since the late 19th or early 20th centuries. Although in the late 20th and the early 21 st centuries the problems associated with them seemed to have been removed from the agenda, they reemerged again in an even more pronounced way after 2011.

There is yet another remarkable thing. The problem of unity is not limited to the regional dimension and becomes quite manifest in each of the WANA societies at all levels up to the personal one.

Indeed, the topical issue of decentralization (alllamrkzia) as a way of settling armed conflicts in Syria, Yemen, and Libya, and reforming governance in Egypt, Tunisia, Algeria, Morocco, and other states (Kerigi, 2017; Abouhani, 2006, pp.9-27) is ultimately tied to the search for new grounds for national unity in these countries. In all cases without exception, decentralization (or federalization) plans, declared or real, serve, using D. North's terminology (North et al, 2011), as an instrument for enlarging the dominant coalition and granting the rent to the groups to which it was earlier denied.

If we look at the states that have advanced far enough along this path (primarily Iraq or Libya), we will see that, following the acquisition of broad autonomy by certain parts of the country, the issue of unity is assuming a regional dimension. This is borne out by the confrontation between Erbil and Sulaymaniyah in Iraqi Kurdistan, by the struggle between various Shi' ite forces in the south of the country, and by the rivalry between Misrata and Zintan in Libya (Lacher and Al-Idrissi, 2018), etc. At the same time, the events of 2019 showed that a mere mention of fragmentariness is not enough to describe the real situation. In all cases without exception we can see the search for new grounds for unity, whereby local identities are competing with regional and national ones.

Finally, attempts to overcome fragmentariness occur both at the social (hence the importance of the gender agenda in Arab social movements (POMEPS Studies, 2019)) and personal, that is, psychological, levels as an urge to overcome frustration in young people who are torn apart between adherence to traditions and their striving for modernity. 
Another feature of neo-modernity is the problematization of values and meanings - in this case, of social and political existence-and the return of ideology.

There is nothing new about the erosion or even disappearance of political ideologies in the postmodern world. Philosophers can argue about whether ideology is being fully replaced by technology (Gadzhiev, 2016) or receding into the shadow of political processes (Rubtsov, 2018), but the fact remains that in both the West and the East, the late 20th and the early 21 st centuries saw the erosion of major ideologies. The most vivid example of that is the deep crisis of traditional political parties not only in Europe and the United States, but also in other regions (Liddiard, 2019). WANA countries fit well into this global trend even before it became mainstream in the West. The absence of ideological motives in the protest movements in 2011 and later seemed to become further proof of this common movement.

However, the situation changed. The key issue of social and political life in all countries swept by the Arab Spring in 2011-2013 was the confrontation between Islamist and secular projects for the development of societies. In some cases, this confrontation took the form of rivalry between political parties; in others, it sparked discussions on constitutional reforms; and still in others, it developed into armed struggle. In each particular case it can be described differently, for example, as a struggle between elites and counter-elites instrumentalizing the religious agenda, but the fact is that the societies viewed the relationship between religion and politics as a key issue at that time.

Almost all countries have found a compromise, and Islamist parties of various types have been integrated into the political systems. This is true even of Egypt, where the Muslim Brotherhood movement has been criminalized since 2013, but other Islamist parties, such as alNour, have proved to be loyal allies of the new political regime. The issue of civilizational choice has not been resolved for good (which is probably hardly possible) but has been removed from the agenda for the time being.

Yet the return of ideology did not end there. The policy of national consolidation mentioned above is accompanied everywhere 
by intensified nationalist discourse, which is particularly evident in religious politics. Turning to the traditional confession of faith becomes an official policy in Tunisia, Egypt, Saudi Arabia, and other countries in the region. Even the Secretary-General of the Muslim World League, Muhammad bin Abdul Karim Issa, an organization formerly considered one of the main instruments of the "Salafi International" (Feur, 2019, pp.24-27), speaks positively of national patriotism. In some cases, the return of ideology is clearly conserving as is the example of Algeria where tiermondism is still quite popular.

Another important element of ideological construction is national development strategies like Saudi Arabia’s Vision 2030 designed to paint an image of the future for a young generation of citizens. These plans lack the scale of the images offered by the great ideologies but, generated by the technocratic age, appear to be quite adequate at the present moment. Combined with nationalist rhetoric, they create an ideology that meets the neo-modernity requirements: not a dream of caliphate, communism, or Arab brotherhood, but a roadmap for development in the coming decades.

Renewed ideological pursuits as a political projection of reemerging metanarratives also imply the establishment of new political mythology.

There is no doubt that ISIS, whose leaders, ideologists, and political technologists attached enormous importance to symbolism, produced the most striking examples of mythology in recent years in WANA (Bunzel, 2015, pp.7-36). It would be wrong to think that its leaders used symbolic politics exclusively for instrumental purposes to create certain images. The myth expressed in symbols constituted the essence of the ISIS ideology of struggle against the "crusaders," Zionists, and polytheists. The fiercest battles between ISIS and al-Qaeda theologians took place in the sacred mythological space (Byman, Williams, 2015). In addition, the traditional set of mythologemes associated with the narratives of early Islam and Arab nationalism was enriched with new images related to the Islamic world's opposition to the aggressive West; hence the orange coveralls on Guantanamo prisoners in videos showing the executions of "infidels."

However, this is not the only case of appealing to myths. 
The Arab Spring in Tunisia and Egypt has brought myths about revolution and revolutionary heroism back into the realm of politics, creating their own pantheons of martyrs and heroes. The most known of them is, of course, Mohamed Bouazizi, who set himself on fire in the Tunisian town of Sidi Bouzid on December 17, 2010. It is quite remarkable that the real biography of the young man, who had just appeared in the media, was mythologized in a matter of days, instantly acquiring details that turned him into a typical victim of the authoritarian regime. And the street vendor who had never studied in university began to be considered an unemployed graduate (France24, 2010).

The fact that one of the central squares in the capital, quickly named after him, was soon renamed, and the memorial plaque bearing his name was dismantled, does not indicate that his image has been demythologized, but rather exposes a controversial attitude towards the revolution, of which he became a symbol.

Such examples abound, some having pan-Arab significance and some being purely local.

The need for new political mythology and the emergence of new symbols are directly related to the personification of political processes across the region and to the search for historical prototypes of presentday leaders. This explains the restoration of the Habib Bourguiba Monument in Tunisia during the presidency of Beji Caid Essebsi who was directly associated with the country's first president; allusions to Gamal Abdel Nasser during Abdel Fattah al-Sisi's rule in Egypt (ElNawawi and El-Masri, 2016), and increasingly common references to Recep Tayyip Erdogan as sultan in the global and regional press.

The distinctive feature of the new situation that makes it basically different from the modern era is that various political metanarratives, ideologies and related symbols coexist and compete within the same political space. The result is, on the one hand, the impossibility of building an integral ideological system, and, on the other, multiple readings of almost every political symbol.

Their coexistence is possible only when postmodern tools, such as irony, play, etc., are widely used in politics. In these circumstances any political statement can be disavowed, any political action can be 
interpreted through the lens of different narratives, and no ideology is perceived in its entirety and plays only a limited role.

A typical example of such irony is the introduction of religious elements into the secular political discourse in different countries of the region, which has not made any of them less secular, though. For example, the Libyan National Army, which launched an offensive in the south and west of Libya in 2019, portrays itself as a fighter against Islamists (Ghanmi, 2019), although a large number of its members are Madkhali-Salafis, whose religious leaders proclaimed a "march to Tripoli" jihad (Arabi Post, 2019). (To be fair, the opposing side also used religious parlance. For example, the commander of the al-Sumud brigade (Misrata), Ahmed bin Omran, spoke against the ceasefire agreements, claiming that "jihad in the way of Allah does not end until complete victory is achieved" (Agenzia Nova, 2019)). At the same time, the Libyan political parties which participated in the first elections after the overthrow of Muammar al-Gaddafi and which proclaimed themselves liberal and democratic, were neither and, having come to power, began their rule with the shariatization of legislation (Lacher, 2013, pp.9-10).

Another example is the policy of the Arab States of the Gulf with regard to the Syrian conflict and Russia's military campaign in Syria. Fierce anti-Russian rhetoric, which at some point became a crucial element of their foreign policy discourse, did not prevent Qatar, the UAE, and Saudi Arabia from seeking cooperation with Moscow, organizing state visits to the Russian capital, and soon starting a careful rapprochement with Damascus, where Bahrain and the UAE reopened their embassies.

Such inconsistency, which can be found both at the national and international levels, creates the impression that the current state of affairs is transient, while in reality this transitivity is fundamental and should not, and even cannot, result in the establishment of rigid systems in any one country or region.

The current study shows that the idea of neo-modernity can be conceptualized further and applied to specific regional reality, although both perspectives need clarification. 
The concept of neo-modernity, which is one of the forms of various post-postmodernisms, in some ways appears to be closer to its other forms, primarily, meta-modernism. It is close but not synonymous. What makes it quite distinct is that, first, it appeals to a slightly different methodological and philosophical tradition (more continental than Anglo-American), and, second, it is intended to address a different range of tasks. Unlike meta-modernism, neo-modernity does not seek to describe a new "structure of feeling," a concept widely used by F. Jameson and accepted by R. van den Akker and T. Vermeulen. Even if it characterizes it in a certain way, it is not the task of the neo-modern approach. Its main purpose is to create a new conceptual framework for describing reality, in my case sociopolitical.

Applying the neo-modern approach to a particular political reality makes it possible to achieve results and describe processes which remained outside of research when other methods were employed. This article is only the first timid attempt at such research. Obviously, further steps will require a kind of pendulum-like interaction between general theoretical and specific regional studies, whereby new results obtained in one field will provide the basis for progress in another.

\section{References}

Abouhani, A., 2006. Etat, systèmes et pouvoirs locaux dans le monde arabe. Pouvoirs locaux et Systèmes municipaux dans le Monde Arabe. Rabat: Institut National d'Aménagement et d'Urbanisme, pp.9-27.

Agenzia Nova, 2019. Libia: brigata Al Sumud a "Nova", "nessun accordo con il criminale di guerra Haftar". Agenzia Nova [online]. Available at: <www. agenzianova.com/a/5cd59c32704506.88660321/2435186/2019-05-10/libiabrigata-al-sumud-a-nova-nessun-accordo-con-il-criminale-di-guerra-haftar/ linked $>$ [Accessed 17 January 2020].

Akopov, S.V. and Krivokhizh, S.V., 2019. Symbolic Representations of "Sovereignty" in Modern Political Discourse (Comparative Analysis of Contemporary Discourse from France, USA, Russia and China). Higher School of Economics Basic Research Program Working Papers. Series: Political Science. WP BRP 65/PS/2019. 
Alekseenkova, E., 2016. Premodernism Revisited. RIAC (Russian International Affairs Council) [online]. Available at: https://russiancouncil.ru/en/analytics-andcomments/analytics/vozrozhdenie-domoderna/ [Accessed 17 January 2020].

Alexander, J., 2013. Smysly social'noì zhizni: kul'tursotsiologiya [The Meanings of Social Life. A Cultural Sociology]. Moscow: Praksis

Alhussein, E., 2019. Saudi First: How Hyper-Nationalism Is Transforming Saudi Arabia. European Council on Foreign Relations. Policy Brief [online]. Available at: $<$ https://www.ecfr.eu/page/-/saudi_first_how_hyper_nationalism_ is_transforming_saudi_arabia.pdf $>$ [Accessed 17 January 2020].

Alrawi, M., 2018. The Pan-Arabism Envisaged by My Grandfather Can Be Replaced by a New Dream. The National. Opinion, 14 August [online]. Available at: $<$ https://www.thenational.ae/opinion/comment/the-pan-arabism-envisagedby-my-grandfather-can-be-replaced-by-a-new-dream-1.898222> [Accessed 17 January 2020].

Anderson, P., 1998. The Origins of Postmodernity. London, New York: Verso. [pdf] Available at: $<$ https://ru.scribd.com/document/62045838/AndersonPerry-Origins-of-Post-Modernity> [Accessed 19 May 2020].

Arabi Post, 2019. Haftar yughazil al-salafiyun li-dukhul tarablus, wa-lakin mayaf'alahu ma'ahum qad yughdibu misr wa-l-imarat [Haftar courts Salaphites into Tripoli but his ways may upset Egypt and the Emirates]. Arabi Post [online] Available at: تحليلات-شارحة/تحليلات/2019/05/14/amp/ [Accessed 17 January 2020].

Baranovsky, V.G. and Naumkin, V.V. (eds.), 2018. Blizhniǔ Vostok $v$ menyayushchemsya globalnom kontekste [The Middle East in the Changing Global Context]. Moscow: RAS Institute of Oriental Studies.

Bayraktari, A., Durand, A., and Norwood-Witts, S., 2000. Neomodern Manifesto [online]. Available at: <http://durand-gallery.com/manifesto/> [Accessed 17 January 2020].

Bunzel, C., 2015. From Paper State to Caliphate: The Ideology of the Islamic State. Brookings. Analysis Paper. No 19, pp.7-36.

Byman, D. and Williams J., 2015. Jihadism's Global Civil Wars. The National Interest. No. 136, pp.10-18.

Ciarkowski, B., 2016. Non-Modern Modernity? Neomodern Architecture. Art Inquiry. Recherches sur les arts. XVIII.

Constantinou, L., 2019. Chetyre lika postironii [For Faces of Post-Irony]. In: R. van den Akker, T. Vermeulen and A. Gibbons, (eds.). Metamodernizm. Istorichnost', 
Affekt i Glubina posle postmodernizma [Metamodernism: Historicity, Affect and Depth after Postmodernism]. Moscow: RIPOL Classic, pp. 221-256.

Denning, G., 2000. A New Critical Aesthetic. [online]. Available at: <https://web. archive.org/web/20070930093518/http:/guydenning.org/neomodern/a_new_ critical_aesthetic.htm> [Accessed 17 January 2020].

Eden, M., 2018. Neo-Modernism: soul nourishing renaissance. Trebuchet [online]. Available at: <http://www.trebuchet-magazine.com/neo-modernism/> [Accessed 17 January 2020].

El Hamalawy, N., n.d. Arab Exceptionalism? A Case Study of Egypt's Regime Breakdown. Lund University [online]. Available at: $<$ http://lup.lub.lu.se/luur/dow nload? func $=$ downloadFile\&recordOId $=2199099 \&$ fileOId $=2205137>$ [Accessed 17 January 2020].

El-Nawawi, M., and El-Masri, M.H., 2016. The Signs of a Strongman: A Semiotic and Discourse Analysis of Abdelfattah Al-Sisi's Egyptian Presidential Campaign. International Journal of Communication. No 10, pp.2275-2296.

Feur, S., 2019. Course Correction. The Muslim World League, Saudi Arabia's Export of Islam, and Opportunities for Washington. Washington: The Washington Institute for Near East Policy.

France 24, 2010. La jeunesse défie le président Zine el-Abidine Ben Ali [ Young people challenge President Zine el-Abidine Ben Ali]. France 24 [online]. Available at: <https://www.france24.com/fr/20101227-jeunesse-defie-ben-alicontre-chomage-precarite-tunisie-police-manifestations-sidi-bouzid $>$ [Accessed 17 January 2020].

Gadzhiev, K.S., 2016. Metamorfozy ideologiī v sovremennoī mirovoī politike [Metamorphosis of Ideologies in World Policy Today]. In: Ye. G. Solovyov (ed.) Partiiyno-politicheskie sistemy i politicheskie ideologii v stranah Zapada $v$ nachale XXI veka: faktory evolyutsii $i$ napravleniya transformatsii [Partisan and Political Systems and Political Ideologies in the West in the Early 21st Century: Factors of Evolution and Vectors of Transformation]. Moscow: IMEMO RAN, pp.8-14.

Ghanmi, L., 2019. LNA says main Islamist militia on the retreat. The Arab Weekly [online]. Available at: <https://thearabweekly.com/lna-says-mainislamist-militia-retreat $>$ [Accessed 17 January 2020].

Gibelev, I., 2017. Neomodern, tranzakcionizm, prostranstvo [Neomodernity, Transactionism, and Space]. RIAC (Russian International Affairs Council) [online]. Available at: <https://russiancouncil.ru/blogs/igorgibelev/33615/?sphrase_id=33213598> [Accessed 17 January 2020]. 
Glukhova, O.Y., 2016. "Manifest neomoderna” A.A. Pelipenko kak sovremennaya antiutopiya [The "Neo-Modernity Manifesto" of A.A. Pelipenko as Modern Antiutopia]. Lichnost'. Kul'tura. Obshchestvo. Vol. XVIII, 3-4(91-92), pp.50-56.

Grauer, V.A., 1981-82. Modernism/Postmodernism/Neomodernism. Downtown Review [online]. Vol. 3 Nos. 1\&2, Fall/ Winter/ Spring. Available at: $<$ http:// doktorgee.worldzonepro.com/MODERN.htm> [Accessed 17 January 2020].

Griffin, R., 2018. Qatar Carves National Identity out of Saudi-led Blockade. MiddleEastEye [online]. Available at: $<$ https://www.middleeasteye.net/opinion/ qatar-carves-national-identity-out-saudi-led-blockade $>$ [Accessed 17 January 2020].

Huber, R.A. and Schumpf, C.P., 2017. On the Distinct Effects of Left-Wing and Right-Wing Populism on Democratic Quality. Politics and Governance [e-journal]. 2017, 5(4), pp.146-165. DOI: 10.17645/pag.v5i4.919. P.146.

Ilyin, M.V., 2011. Strukturnye parametry neblagopoluchiya gosudarstv [Structural Parameters of States' Ill-Being]. In: M.V. Ilyin and I.V. Kudryashova (eds.). Asimmetriya mirovoī sistemy suvereniteta: zony problemnoī gosudarstvennosti [Asymmetry of the World's System of Sovereignty: Territories of Statehood in Question]. Moscow: MGIMO University, pp.20-46.

Jameson, F., 2019. Postmodernizm, ili Kul'turnaya logika pozdnego kapitalizma [Postmodernism, Or the Cultural Logic of Late Capitalism]. Moscow: Gaidar Institute.

Karolak, M., 2019. Gulf Countries: The Struggle for a Common Identity in a Divided GCC. ISPI [online]. Available at: <https://www.ispionline.it/sites/ default/files/pubblicazioni/commentary_karolak_16.05.2019.pdf $>$ [Accessed 17 January 2020].

Kelly, A., 2010. David Foster Wallace and the New Sincerity in American Fiction. In: D. Hering (ed.) Consider David Foster Wallace. Critical Essays. Los Angeles/ Austine: Sideshow Media Group Press, pp.131-146.

Kherigi, I., 2017. Devolving Power After the Arab Spring: Decentralization as a Solution. Al Shark [online]. Available at: <https://research.sharqforum. org/2017/03/30/devolving-power-after-the-arab-spring-decentralization-as-asolution/> [Accessed 17 January 2020].

Kinninmont, J., 2019. The Gulf Divided. The Impact of the Qatar Crisis. Chatham House. Research Paper [online]. Available at: <https://www.chathamhouse.org/ sites/default/files/publications/research/2019-05-30-Gulf\%20Crisis_0.pdf > [Accessed 17 January 2020]. 
Kortunov, A.V., 2017. From Post-Modernism to Neo-Modernism. Russia in Global Affairs. 1 January/March [online]. Available at: < https://eng.globalaffairs.ru/ articles/from-post-modernism-to-neo-modernism/> [Accessed 17 January 2020] Kuznetsov, V.A., 2018. Potaonnye tropy Tunisa. Zhit' i rasskazyvat' revolyuciyu [Secret Paths of Tunis: To Live and Tell the Revolution]. Moscow: RAS Institute of Oriental Studies, GAUGN-Press.

Kuznetsov, V.A., 2019. Western Asia and North Africa in the Neo-Modernity Context. Russia in Global Affairs, 1 January/March [online]. Available at: < https://eng.globalaffairs.ru/articles/western-asia-and-north-africa-in-the-neomodernity-context/> [Accessed 17 January 2020]; DOI: 10.31278/1810-63742019-17-1-124-146.

Lacher, W., 2013. Fault Lines of the Revolution. Political Actors, Camps and Conflicts in the New Libya. SWP Research Paper [online]. Available at: <https:// www.swp-berlin.org/fileadmin/contents/products/research_papers/2013_RP04_ lac.pdf> [Accessed 17 January 2020].

Lacher, W. and al-Idrissi A., 2018. Capital of Militias. Tripoli's Armed Groups Capture the Libyan State. SANA Briefing Paper, 18 June [pdf]. Available at: $<$ http://www.smallarmssurvey.org/fileadmin/docs/T-Briefing-Papers/SASSANA-BP-Tripoli-armed-groups.pdf $>$ [Assessed 17 January 2020].

Liddiard, P., 2019. What Can Be Done About the Problem of Political Parties. Wilson Center [online]. Available at: <https://www.wilsoncenter.org/sites/default/ files/media/documents/publication/liddiard_what_can_be_done_about_the_ problem_of_political_parties_september_2019.pdf> [Accessed 17 January 2020]. Lyotard, J.F., 1998. Sostoyanie postmoderna [The State of Postmedernity]. Moscow: Aleteia.

North, D., Wallis, J. and Weingast, B., 2011. Nasilie i social'nye poryadki. Kontseptual'nye ramki dlya interpretatsii pis'mennō istorii chelovechestva [Violence and Social Orders: Conceptual Framework for Interpreting Recorded Human History]. Moscow: Gaidar Institute.

Pavlov, A.V., 2019. Filosofiya kul'tury v postpostmodernizme: kriticheskii analiz [Postmodern Cultural Philosophy: A Critical Analysis], PhD Theses. Moscow: RAS Institute of Philosophy.

Pelipenko, A.A., 2016. Manifest neomoderna [NeoModernity Manifesto]. Lichnost'. Kul'tura. Obshchestvo. Vol. XVIII, 3-4(91-92), pp, 40-49.

POMEPS Studies, 2016. Women and Gender in Middle East Politics [online]. Available at: <https://pomeps.org/wp-content/uploads/2016/05/POMEPS_ Studies_19_Gender_Web.pdf> [Accessed 17 January 2020]. 
Rubtsov, A.V., 2018. Illyuziya deideologizatsii [The Illusion of Deidealogization]. In: A.A. Guseinov, A.V. Rubtsov, eds., 2018. Filosofiya i ideologiya: ot Marksa do postmoderna [Philosophy and Ideology: From Marx to Post-Modernity]. Moscow: Progress-Traditsya, pp.114-128.

Rudenkin, D. and Loginov, A., 2018. Ideologiya v obshchestve pozdnego moderna: ischeznovenie ili transformatsiya? [Ideology in the Late Modern Society: Dissolution or Transformation?] Sociologicheskoe Obozrenie, 17(3), pp.202-205.

Shakir Karim Abd, 2020. Masar al-Iraq Alllathi nurid [The Iraqi Way We Want].

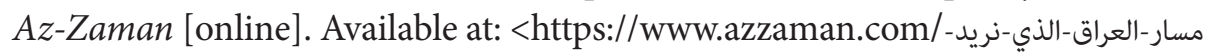
اشاكر-كريم-عبد/> [Accessed 17 January 2020].

Soler I Lecha E. et al., eds., 2016. Middle East and North Africa Regional Architecture: Mapping Geopolitical Shifts, Regional Order and Domestic Transformation. Methodology and Concept Papers. No. 1. [online]. Available at: https:// www.iai.it/sites/default/files/menara_cp_1.pdf [Accessed 17 January 2020].

Stelmach, M., 2016. Slow Expansion. Neomodernism as a Postnational Tendency in Contemporary Cinema. Transmissions: The Journal of Film and Media Studies. 1 (2), pp.100-117.

Tiryakian, E.A., 1991. Modernization: Exhumetur in pace. International Sociology, 6(2), pp.165-180.

Tiryakian, E.A.,1996. Rethinking modernization: legacies of Parsons and Hilbert. WZB Discussion Paper. III, pp.96-406

Van den Akker, R. and Vermeulen, T., 2019. Periodiziruya 2000-e, ili Poyavlenie metamodernizma [Periodizing the 2000s, or the Emergence of Metamodernism]. In: R. van den Akker, T. Vermeulen and A. Gibbons, (eds). Metamodernizm. Istorichnost', Affekt i Glubina posle postmodernizma [Metamodernism: Historicity, Affect and Depth after Postmodernism]. Moscow: RIPOL Classic, pp.39-82.

Vyazmitinova, L., 1999. "Mne stydno ottogo, chto ya rodilsya krichashchī̄, krasnyī, s uzhasom - v krovi..." [I am embarrassed to be born yelling, red, in fear - and in blood...]. Literaturnoe obozrenie, 5(6) [online]. Available at: <http:// www.levin.rinet.ru/FRIENDS/VODENNIKOV/about/about-3.html $>$ [Accessed 17 January 2020]

Wimmen, H., 2019. Lebanon's Revolt. International Crisis Group [online]. Available at: <https://www.crisisgroup.org/middle-east-north-africa/easternmediterranean/lebanon/lebanons-revolt> [Accessed 17 January 2020].

Zhitenev, A.A., 2012. Poeziya neomodernizma: monografiya [Neomodernist Poetry: A Monograph]. Saint Petersburg: INA-PRESS. 